\title{
THE TRANSPORT AND EXCRETION OF URIC ACID IN MAN. I. TRUE URIC ACID IN NORMAL CEREBROSPINAL FLUID, IN PLASMA, AND IN ULTRAFILTRATES OF PLASMA
}

\author{
By W. Q. WOLFSON, R. LEVINE, AND M. TINSLEY \\ (From the Department of Metabolism and Endocrinology 1 and the Department of Neurology, \\ Michael Reese Hospital, Chicago, Illinois)
}

(Received for publication March 7, 1947)

Human cerebrospinal fluid has been reported to contain a relatively small concentration of uric acid compared to that of plasma ( $c f$. Table II). However, it is not known what proportion of these reported uric acid values is due to chromogenic substances similar to those giving the color reaction for uric acid in plasma (1). The introduction of enzymatic methods for determining uric acid specifically ( 2 to 5 ) has made reexamination of spinal fluid values advisable, particularly with regard to their relation to plasma ultrafiltrates.

\section{SUBJECTS}

Cerebrospinal fluids ${ }^{2}$ were obtained by lumbar puncture from individuals suspected of neurosyphilis and from others undergoing routine follow-up after antiluetic therapy. Those fluids which were serologically and Pandy negative were combined into $10-\mathrm{ml}$. pools, each pool representing 5 individuals. Total protein was then determined on each pool and those with a content of less than $35 \mathrm{mgm}$. per $100 \mathrm{ml}$. were considered satisfactory for study.

Ventricular fluids were obtained during diagnostic ventriculography on neurological patients without mass lesions or inflammatory intracranial disease.

Plasma for ultrafiltration was obtained from 2 normal subjects on diets of varying purine content. The results quoted in the text are the average of 8 determinations on one subject and $\mathbf{5}$ on the second.

\section{METHODS}

Uric acid was determined in plasma, plasma ultrafiltrates, and in cerebrospinal fluid by a modification of the method of Buchanan, Block and Christman (2) for the Evelyn photoelectric colorimeter.

The essentials of this determination and the terms used in reporting results are as follows:

1. A 1-ml. aliquot of the specimen is deproteinated and the color developed with the arsenophosphotungstic acid

\footnotetext{
1 The department is in part supported by the Michael Reese Research Foundation.

2 The authors are indebted to the Hektoen Institute for Medical Research of Cook County Hospital for cooperation in obtaining. cerebrospinal fluid specimens.
}

and urea-cyanide reagents. The concentration of uric acid equivalent to the color developed is termed total urate.

2. Another (2-ml.) aliquot of the specimen is treated with uricase at $\mathrm{pH} 9.1$ to destroy the uric acid present. It is then treated as above, the color developed being termed chromogen.

3. The difference between the values for total urate and for chromogen represents the amount of uric acid destroyed by the specific enzyme and is therefore termed true urate.

The actual size of the aliquots given in the preceding paragraph is that used in plasma determinations; cerebrospinal fluid contains so little urate that it is advisable to use twice or 3 times these amounts.

The nature of the chromogenic substances in plasma and urine which give the color reaction for urate has been discussed recently (1) and will be reviewed more comprehensively in a forthcoming publication (6). A portion of the chromogen is non-purine in origin, but another portion is due to an incompletely characterized purine metabolite (or metabolites) of endogenous origin. In addition, methylurates from the methylxanthines of dietary origin contribute to the chromogen.

The normal plasma urate values quoted are based upon repeated determinations on 31 normal individuals and are similar to the values obtained by Bulger and Johns (3) with a uricase method.

Plasma for ultrafiltration was obtained from blood drawn in a heparinized syringe and immediately centrifuged; no attempt was made to preserve the normal carbon dioxide content. Ultrafiltrates of plasma were obtained by a modification of the method of Lavietes (7). The membranes used were DuPont No. 600 cellophane, soaked 3 days at $0^{\circ}$ before used. ${ }^{3}$

\section{RESULTS}

The results of the urate partition in pooled normal cerebrospinal fluid are given in Table I, together with the average normal concentrations in plasma and the calculated C.S.F./plasma ratios. These data show that normal human cerebrospinal fluid appears to contain, on the average, only 6

8 The cellophane membranes used in ultrafiltration were made available through the cooperation of E. I. du Pont de Nemours $C$. 
TABLE I

Urate content of normal human cerebrospinal fluid and calculated average C.S.F./plasma ratio

\begin{tabular}{|c|c|c|c|c|}
\hline & $\begin{array}{l}\text { Total } \\
\text { urate }\end{array}$ & $\underset{\text { gen }}{\text { Chromo- }}$ & $\begin{array}{l}\text { True } \\
\text { urate }\end{array}$ & $\begin{array}{l}\text { Total } \\
\text { protein }\end{array}$ \\
\hline $\begin{array}{c}\text { C.S.F. pools } \\
1 \\
2 \\
3 \\
4 \\
5 \\
6 \\
7 \\
8 \\
9\end{array}$ & $\begin{array}{c}\text { mgm. per } \\
100 \text { ml. } \\
0.58 \\
0.35 \\
0.80 \\
0.58 \\
0.76 \\
0.62 \\
0.51 \\
0.67 \\
0.59\end{array}$ & $\begin{array}{c}\text { mgm. per } \\
\text { 100 ml. } \\
0.26 \\
0.28 \\
0.60 \\
0.38 \\
0.33 \\
0.38 \\
0.38 \\
0.38 \\
0.33\end{array}$ & $\begin{array}{c}\text { mgm. per } \\
\text { 100 ml. } \\
\\
0.32 \\
0.07 \\
0.20 \\
0.20 \\
0.43 \\
0.24 \\
0.13 \\
0.29 \\
0.26\end{array}$ & $\begin{array}{c}\text { mgm. per } \\
100 \text { ml. } \\
\\
20 \\
25 \\
30 \\
13 \\
10 \\
13 \\
13 \\
14 \\
13\end{array}$ \\
\hline $\begin{array}{l}\text { Average } \\
\text { C.S.F. } \\
\text { concentration }\end{array}$ & 0.61 & 0.37 & 0.24 & \\
\hline $\begin{array}{l}\text { Average } \\
\text { plasma } \\
\text { concentration }\end{array}$ & 4.76 & 0.74 & 4.02 & \\
\hline $\begin{array}{l}\text { Average } \\
\text { C.S.F./plasma } \\
\text { ratio }\end{array}$ & 0.13 & 0.50 & 0.06 & \\
\hline
\end{tabular}

per cent of the true urate present in plasma. Furthermore, application of the uricase method to spinal fluid shows that slightly less than half the chromogenic material present is true urate.

Our results for total urate in cerebrospinal fluid are comparable to those found in previous investigations, which are summarized in Table II. The values found by Katzenellenbogen (12) are somewhat lower than those in other studies because he employed a silver precipitation method which yields values approximately equivalent to true urate under suitable circumstances (1). Normal values in children are reported to be 50 per cent higher than in adults (16).

The C.S.F./plasma ratios reported by different investigators show considerable variation; but most recent studies show a mean ratio of 0.1 to 0.2 for total urate. Reiche (9), by dividing his large material into 3 groups, was able to show a rough parallelism between the blood urate level and the cerebrospinal fluid level.

We have secured a small number of ventricular fluids from patients without mass lesions of the brain or inflammatory intracranial disease. These data, presented in Table III, show merely that the urate content and partition in ventricular fluid do
TABLE $\mathbf{I}$

Plasma and cerebrospinal fluid total urate values reported in various investigations

\begin{tabular}{|c|c|c|c|c|c|}
\hline Authors & $\begin{array}{l}\text { Source of } \\
\text { material }\end{array}$ & $\begin{array}{l}\text { Aver- } \\
\text { age } \\
\text { C.S.F. }\end{array}$ & $\begin{array}{c}\text { Aver- } \\
\text { age } \\
\text { serum } \\
\text { or } \\
\text { blood }\end{array}$ & $\frac{\text { C.S.F. }}{\text { Blood }}$ & $\frac{\text { C.S.F. }}{\text { Plasma }}$ \\
\hline & & $\begin{array}{c}\text { mgm. } \\
\text { per } \\
100 \mathrm{ml} .\end{array}$ & $\begin{array}{c}\text { mgm. } \\
\text { per } \\
100 \mathrm{ml} .\end{array}$ & & \\
\hline $\begin{array}{l}\text { Present investi- } \\
\text { gation }\end{array}$ & $\begin{array}{l}\text { Pooled normal } \\
\text { specimens }\end{array}$ & 0.61 & $\begin{array}{c}4.76 \\
\text { plasma }\end{array}$ & & 0.128 \\
\hline $\begin{array}{c}\text { Cantarow and } \\
\text { Trumper (8) }\end{array}$ & $\begin{array}{l}\text { Normal indi- } \\
\text { viduals }\end{array}$ & 0.63 & $\begin{array}{l}3.00 \\
\text { blood }\end{array}$ & 0.210 & $\begin{array}{c}0.158^{*} \\
\text { Estimated }\end{array}$ \\
\hline Reiche (9) & $\begin{array}{l}230 \text { medical } \\
\text { patients }\end{array}$ & 1.28 & $\begin{array}{l}4.46 \\
\text { blood }\end{array}$ & 0.287 & $\begin{array}{l}\mathbf{0 . 2 1 5 ^ { * }} \\
\text { Estimated }\end{array}$ \\
\hline Frada (10) & 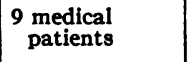 & 0.89 & $\begin{array}{c}4.82 \\
\text { blood }\end{array}$ & 0.185 & $\begin{array}{c}\text { 0.139** } \\
\text { Estimated }\end{array}$ \\
\hline Ingvarsson (11) & $\begin{array}{l}33 \text { schizophrenic } \\
\text { patients }\end{array}$ & 0.47 & $\begin{array}{c}2.79 \\
\text { blood }\end{array}$ & 0.168 & $\begin{array}{c}0.126^{*} \\
\text { Estimated }\end{array}$ \\
\hline $\begin{array}{l}\text { Katzenellen- } \\
\text { bogen (12) }\end{array}$ & $\begin{array}{l}20 \text { schizophrenic } \\
\text { patients }\end{array}$ & 0.19 & $\begin{array}{c}2.49 \\
\text { blood }\end{array}$ & 0.076 & $\begin{array}{c}\mathbf{0 . 0 5 7 *} \\
\text { Estimated }\end{array}$ \\
\hline Cockrill (13) & 5 normal & 1.83 & $\begin{array}{c}4.53 \\
\text { plasma }\end{array}$ & & 0.404 \\
\hline $\begin{array}{c}\text { Chauffard, } \\
\text { Brodin and } \\
\text { Grigaut (14) } \\
\end{array}$ & 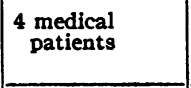 & 0.54 & $\begin{array}{l}4.84 \\
\text { serum }\end{array}$ & & 0.112 \\
\hline Talbott (15) & $\begin{array}{l}12 \text { gouty } \\
\text { patients }\end{array}$ & 1.79 & $\begin{array}{l}7.26 \\
\text { serum }\end{array}$ & & 0.246 \\
\hline
\end{tabular}

* Depending chiefly upon the hematocrit and upon the type of whole blood method used, C.S.F./blood ratios will average 135 to 200 per cent of C.S.F./plasma ratios. To facilitate comparison of data, where authors determined urate in blood the C.S.F./plasma ratio in the final column has been estimated as 0.75 (C.S.F./blood).

not differ strikingly from that obtained by lumbar puncture.

The difference between plasma and cerebrospinal fluid urate concentrations is so large that it

TABLE III

Urate concentration and partition in ventricular fluid obtained from patients without mass lesions or inflammatory intrecranial disease

\begin{tabular}{|c|c|c|c|c|c|}
\hline $\begin{array}{c}\text { Sample } \\
\text { num- } \\
\text { ber }\end{array}$ & Diagnosis & $\begin{array}{l}\text { Total } \\
\text { urate }\end{array}$ & $\begin{array}{l}\text { Chro- } \\
\text { mogen }\end{array}$ & $\begin{array}{l}\text { True } \\
\text { urate }\end{array}$ & $\begin{array}{l}\text { Pro- } \\
\text { tein }\end{array}$ \\
\hline V2 & $\begin{array}{l}\text { Cerebral atrophy, } \\
\text { etiology unknown }\end{array}$ & $\begin{array}{c}\underset{\text { mgm. }}{\text { per }} \\
100 \mathrm{ml} . \\
1.30\end{array}$ & $\left|\begin{array}{c}\text { mgm. } \\
\text { per } \\
100 \mathrm{ml} . \\
0.90\end{array}\right|$ & $\begin{array}{c}\underset{\text { per }}{\text { per }} \\
100 \mathrm{ml} . \\
0.40\end{array}$ & $\begin{array}{c}\text { mgm. } \\
\text { per } \\
100 \mathrm{ml} . \\
19\end{array}$ \\
\hline V3 & $\begin{array}{l}\text { Chronic internal } \\
\text { hydrocephalus }\end{array}$ & 0.50 & 0.10 & 0.40 & 20 \\
\hline V4 & $\begin{array}{l}\text { Undiagnosed lesion, } \\
\text { region of optic chiasm }\end{array}$ & 0.70 & 0.50 & 0.20 & 34 \\
\hline \multirow[t]{2}{*}{ V5 } & $\begin{array}{l}\text { Arteriosclerotic cere- } \\
\text { bral vascular disease }\end{array}$ & 0.70 & 0.30 & 0.40 & 19 \\
\hline & Average & 0.80 & 0.45 & 0.35 & 23 \\
\hline
\end{tabular}


TABLE IV

Ultrafiltrability of urate fractions through cellophane in 2 normal subjects (10)

\begin{tabular}{|c|c|c|}
\hline & \multicolumn{2}{|c|}{ Subjects } \\
\hline & W.Q.W.* & H. B.W.† \\
\hline $\begin{array}{l}\text { Plasma total urate, } \\
\text { mgm. per } 100 \mathrm{ml} \text {. } \\
\text { Ultrafiltrate total urate, } \\
\text { mgm. per } 100 \mathrm{ml} \text {. } \\
\text { Per cent ultrafiltrable }\end{array}$ & $\begin{array}{c}7.13 \\
5.29 \\
74.3\end{array}$ & $\begin{array}{r}4.52 \\
3.78 \\
83.6\end{array}$ \\
\hline $\begin{array}{l}\text { Plasma chromogen, } \\
\text { mgm. per } 100 \mathrm{ml} \text {. } \\
\text { Ultrafiltrate chromogen, } \\
\text { mgm. per } 100 \mathrm{ml} \text {. } \\
\text { Per cent ultrafiltrable }\end{array}$ & $\begin{array}{c}1.41 \\
1.12 \\
79.2\end{array}$ & $\begin{array}{r}0.92 \\
0.85 \\
92.4\end{array}$ \\
\hline $\begin{array}{l}\text { Plasma true urate, } \\
\text { mgm. per } 100 \mathrm{ml} \text {. } \\
\text { Ultrafiltrate true urate, } \\
\text { mgm. per } 100 \mathrm{ml} \text {. } \\
\text { Per cent ultrafiltrable }\end{array}$ & $\begin{array}{r}5.72 \\
4.17 \\
72.9\end{array}$ & $\begin{array}{l}3.60 \\
2.93\end{array}$ \\
\hline
\end{tabular}

* Average of 8 experiments, 3 of which were during high purine diet periods.

$\dagger$ Average of 5 experiments, all on normal diet.

clearly cannot be explained on the basis of the Donnan phenomenon. Since the only other clearly established cause for such a discrepancy between spinal fluid and plasma constituents is nondiffusibility, ordinarily due to the binding of a substance to plasma protein, we attempted to determine the degree of protein binding of urate by pressure ultrafiltration through cellophane.

Adlersberg, Grishman and Sobotka (17) have reviewed the literature dealing with attempts to demonstrate protein binding of urate. In their own experiments, they found 84 per cent of the plasma total urate ultrafiltrable in normal individuals.

Our experience with ultrafiltration confirms that of Adlersberg and his coworkers. We found 79 per cent of the plasma total urate and 77 per cent of the plasma true urate to be free to ultrafiltration (Table IV). It is obvious that the quantities of true urate in normal cerebrospinal fluid are much less than those which appear to be free in plasma when cellophane ultrafiltration is used to indicate the degree of plasma binding.

\section{DISCUSSION}

The data presented above demonstrate the cerebrospinal fluid true urate concentration to be only 6 per cent of that present in plasma. The question therefore arises by what mechanism such an unequal distribution may be maintained.

Cerebrospinal fluid, it is generally agreed, resembles a modified ultrafiltrate of plasma $(8,18$, 19). It appears to be subject to alterations predicted by the Gibbs-Donnan rule. Various substances are present in relatively small amounts because of plasma binding and, to a lesser extent, because they may circulate in plasma water in a colloidal state (calcium, bilirubin, cholesterol, salicylate). The quantity of magnesium in cerebrospinal fluid is greater than in plasma and the difference is magnified when plasma binding is considered; it has, however, been suggested that magnesium is a brain metabolite. There remain differences in potassium, glucose, and phosphate partition which cannot be well explained at present.

When true uric acid is considered, there appears to be little resemblance between cerebrospinal fluid and plasma ultrafiltrates. The ultrafiltrate contains 77 per cent of the uric acid concentration of plasma, while the cerebrospinal fluid contains only $1 / 10$ as much urate as the ultrafiltrate.

Three possibilities have been suggested to explain the peculiarity in urate distribution; they will be briefly listed without extended discussion. The first is that true uric acid enters the cerebrospinal fluid in somewhat greater concentration and is converted to substances not fermentable by uricase. Since a small series of determinations of urate partition in ventricular fluid show no differences from fluid obtained by lumbar puncture, this appears not to be tenable.

The second possibility is that the modified ultrafiltration theory of cerebrospinal fluid formation does not apply to true uric acid. Reiche's (9) demonstration of parallelism between blood and spinal fluid urate concentrations makes this appear improbable.

The third possibility is that ultrafiltration through cellophane does not truly reflect the diffusibility of urate through biological membranes. Such behavior is observed in the case of p-aminohippuric acid which shows much greater binding in clearance studies than in ultrafiltration studies (20). From electrophoretic experiments, Bennhold (21) concluded that uric acid is bound to plasma albumin by a linkage highly labile to pressure and that the degree of plasma binding was 
much greater than could be shown by ultrafiltration. Although it is not clear that non-diffusibility is entirely due to binding to plasma protein, evidence obtained from a study of renal and other biological functions $(6,22)$ suggests that the true urate content of the cerebrospinal fluid may be essentially equal to the plasma-free true urate.

\section{SUM MARY}

The concentration of true uric acid in normal human cerebrospinal fluid has been determined enzymatically. Substances giving the arsenophosphotungstate color reaction for urate are present in considerable amount, but true urate forms only 40 per cent of these substances. The concentration of true urate in normal spinal fluids averages 6 per cent of that in normal plasma.

Approximately 77 per cent of the plasma true urate is ultrafiltrable through a cellophane membrane under pressure, but spinal fluid contains only $1 / 10$ the true urate which is found in a plasma ultrafiltrate.

The various possible explanations of these findings are briefly considered.

\section{BIBLIOGRAPHY}

1. Levine, R., Wolfson, W. Q., and Huddlestun, B., A purine metabolite in plasma, which gives the same color reaction as uric acid. Proc. Am. Federation Clin. Research, 1945, 2, 56.

2. Buchanan, O., Block, W. D., and Christman, A. A., Metabolism of the methylated purines. I. Enzymatic determination of urinary uric acid. J. Biol. Chem., 1945, 157, 161.

3. Bulger, H. A., and Johns, H. E., The determination of plasma uric acid. J. Biol. Chem., 1941, 140, 427.

4. Blauch, M, B., and Koch, F. C., A new method for the determination of uric acid in blood, with uricase. J. Biol. Chem., 1939, 130, 443.

5. Schaffer, N. K., The determination of uric acid in urine with crude uricase. J. Biol. Chem., 1944, 153, 163.
6. In preparation.

7. Lavieties, P. H., Anaerobic ultrafiltration. J. Biol. Chem., 1937, 120, 267.

8. Cantarow, A. and Trumper, M., Clinical Biochemistry, W. B. Saunders Co., Philadelphia, 1945, Third Edition, pp. 102, 508-513.

9. Reiche, F., Die Harnsäure im Blut und Liquor und in pathologischen Flüssigkeiten. Ztschr. f. klin. Med., 1933, 125, 565.

10. Frada, G., Sul contenuto in acido urico del liquido cerebro-spinale. Biochem. e terap. sper., 1938, 25, 464.

11. Ingvarrson, G., Eine Studie über den Harnsäuregehalt des Liquor cerebrospinalis bei einigen psychotischen Zuständen. Acta psychiat et neurol., 1937, 12,61 .

12. Katzenellenbogen, S., Studies in schizophrenia; chemical analyses of blood and cerebrospinal fluid. Arch. Neurol. \& Psychiat., 1937, 37, 881.

13. Cockrill, J. R., Nonelectrolytes; their distribution between the blood and the cerebrospinal fluid. Arch. Neurol. \& Psychiat., 1931, 25, 1297.

14. Chauffard, A., Brodin, P., and Grigaut, A., Diffusibilité clinique comparée de l'acide urique et de l'urée. Compt. Rend. Soc. Biol., 1922, 86, 355.

15. Talbott, J. H., Gout. Oxford University Press, New York, 1943.

16. Cantarow, A. A., Personal communication.

17. Adlersberg, D., Grishman, E., and Sobotka, H., Uric acid partition in gout and in hepatic disease. Arch. Int. Med., 1942, 70, 101.

18. Flexner, L. B., The chemistry and nature of the cerebrospinal fluid. Physiol. Rev., 1934, 14, 161.

19. Katzenellenbogen, S., The Cerebrospinal Fluid and its Relation to the Blood. Johns Hopkins Press, Baltimore, 1935.

20. Smith, H. W., Finklestein, N., Aliminosa. L., Crawford, B., and Graber, M., The renal clearances of substituted hippuric acid derivatives and other aromatic acids in the dog and man. J. Clin. Invest., 1945, 24, 388.

21. Bennhold, H., Kylin, E., and Rusznyak, S., Die Eiweisskörper des Blutplasmas. Theodor Steinkopf, Dresden, 1938.

22. Levine, R., and Wolfson, W. Q., What is gout? Newer knowledge of pathological physiology. Proc. Inst. Med. Chicago, 1946, 16, 235. 